\title{
The WTO’s dispute settlement mechanism
}

\author{
by Philip Ruttley
}

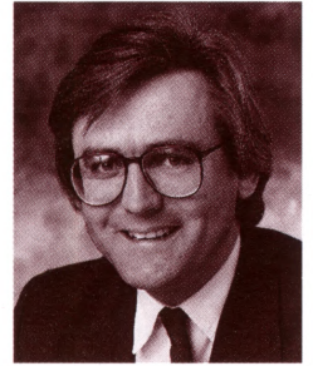

Philip Ruttley describes the way in which international businesses - with particular reference to Japanese companies operating in Europe - can use the new dispute settlement system of the World Trade Organisation to their advantage.

$\boldsymbol{N}_{t}^{\mathrm{t}}$ is fair to say that the World Trade Organisation (WTO) agreements constitute the most far-reaching set of trade treaties ever created by the international community. The WTO agreements range from the new General Agreement on Tariffs and Trade of 1994 (GATT 1994), which is concerned with manufactured goods, to an agreement on trade in services, the General Agreements on Trading Services (GATS), which covers most types of services, with the notable exclusion of financial services. However the WTO is currently planning to have concluded its negotiations for a financial services regulation agreement by December 1997. Now that telecommunications services are regulated under the WTO, the only major types of services which are not yet regulated by an international WTO agreement are aviation and maritime services.

Another important WTO agreement is the agreement on Trade-Related Aspects of Intellectual Property Rights (TRIPS). There is also an agreement regulating government procurement, another on technical barriers to trade and even an agreement on dairy produce. All of these agreements form a package of some 30,000 pages of treaties which now bind the international trading community. They are published together by the WTO in one volume: The Results of the Uruguay Round of Multilateral Trade Negotiations - The Legal Texts (1995).

\section{WIDE-RANGING SYSTEM}

The WTO's membership encompasses most major trading nations, with the notable exception of Russia, the People's Republic of China, Taiwan and Saudi Arabia. Nevertheless, these four countries have all applied for WTO membership and it is expected that by the year 2000, they should all be WTO members.

From a legal point of view, the WTO agreements are a revolution in international trade law. One of the central features of the WTO system is the creation of what amounts to an international trade arbitration tribunal with binding jurisdiction on the 130 states which have joined the WTO since its establishment in 1994. This new system amounts to a legal revolution because the results of the WTO's dispute settlement contrasts with a largely flexible and diplomatic nature of dispute settlement rulings under the old, pre-1994, GATT system.

\section{DISPUTE SETTLEMENT MECHANISM}

Before going into the technicalities as to how private industry can use the WTO system, the WTO's dispute settlement mechanism must be explained.

It has several important and novel features. The first feature of the new system is that it is an integrated legal system, in so far as the WTO agreements are designed to all be regulated under the same system. Thus art. 2.1 of the WTO Framework Agreement states that:

'the WTO shall provide a common institutional framework for the conduct of trade relations amongst its members in matters related to the [WTO agreements].'

A further feature of the system is that it is careful to describe very precisely the hierarchy of legal systems which it contains. Thus, unless otherwise provided under the specific agreement in question, the WTO is to be:

'guided by the decisions procedures, and customary practices followed by the contracting parties to the GATT 1947 and the bodies established under the framework of GATT 1947'. (art. 16)

There is also provision for the assignment of legal priority in cases of conflicts.

A further feature is that the WTO agreements greatly limit unilateral action by states or agreements as between the parties of the WTO but outside the WTO dispute settlement system (inter-se agreements). Basically WTO disputes must always be litigated through the dispute settlement body of the WTO, and there are very considerable limits on voluntary restraint agreements, or bilateral restraint agreements.

The old GATT dispute settlement system was fundamentally weakened by the ability of even the losing state to veto the adoption of a recommendation from a GATT panel. So if there was a dispute under the old GATT, unless there was a consensus of the GATT states to adopt the recommendations of a panel. ruling on a GATT treaty violation, the report of the panel had no legal effect. Unfortunately, many states (particularly European Union countries and the US) exercised this right of 
veto which rendered the old GATT system largely a diplomatic and voluntary agreement.

\section{THE NEW SYSTEM}

This system has been completely changed by the WTO agreement. Under the new dispute settlement understanding, where there is a dispute between WTO states as to the implementation of a WTO agreement, the parties are required to enter into a first phase of consultation to attempt to find an amicable solution to their problems. If that fails, the parties may request the WTO to establish a panel to examine the question in detail. That panel will hear evidence and arguments of the parties and will come to a conclusion with recommendations as to how any violation of the WTO agreements that it has found to exist should be remedied. The third phase is the possibility of an appeal on a point of WTO law to the appellate body which is a new creation of the WTO system and is made up of seven members who have power to overturn panel recommendations.

The revolutionary novelty of the WTO system is that the recommendations of a panel or the rulings of the appellate body are legally binding on member states, unless there is a consensus of member states not to adopt them. This means that the losing state no longer has the right automatically to veto the results of a dispute settlement proceeding. It is highly unlikely, if not impossible, for the victorious state to veto the adoption of a panel or an appellate body ruling. Consequently one can fairly conclude that the new WTO system creates a binding dispute settlement system for international trade.

\section{GROWTH IN LITIGATION}

The new system therefore provides an exciting and ultimately very powerful way to resolve international trade disputes. Not surprisingly, there has been an absolute explosion of litigation since the system finally came into full operation in February 1996. Since then there have been no less than 87 cases presented to the WTO for resolution, and the pace is increasing. Indeed one can express serious concern about whether the limited resources of the WTO secretariat - in particular the small size of the appellate body which has only seven members - will be able to cope with this enormous case-load.

The types of dispute which have been presented to the WTO range over a wide number of WTO agreements. Most often these concern alleged violation of the GATT agreement, or the TRIPS. So far, only five cases have gone the full cycle from complaint to conciliation to a panel and to the appellate body. These concern agricultural products, environmental legislation and taxation.

The Japan Alcohol case is a classic illustration of how private industry can use the WTO dispute settlement system. The Scotch Whisky Association was the main complainant against Japanese domestic taxes on alcohol produce. Effectively it claimed that the Japanese local tax on liquor (Shuzeiho) discriminated against whisky, cognac and white spirits (all of which were exported to Japan) by taxing the Japanese product, sochu, less.

The dispute went before the WTO after the Scotch Whisky Association persuaded the European Commission to bring a formal complaint against Japan. The matter went all the way through the cycle up to the appellate body, which finally had to determine whether sochu and whisky, brandy and other liquors were either 'like' products or 'directly competitive or substitutable' products under art. 3 of the 1994 GATT. The WTO panel and the appellate body both ruled that Japanese alcohol taxation rules were a discriminatory protective barrier against exports of whisky and similar alcohol products, which was unjustifiable. Japan has now announced that it will amend its tax laws and open the market in Japan to exports to a much greater extent than was the case before.

What is very significant about this case is that the Scotch Whisky Association worked hand-in-hand with the European Commission, giving it copious information and evidence in order for the Commission (with its limited resources of staff) to argue the case before the WTO panel.

\section{USING THE WTO SYSTEM}

I now want to turn onto the different ways in which the WTO dispute settlement mechanism can be used by private industry. Naturally, being a European lawyer, my remarks will primarily describe the situation in the European Community. This is also of relevance for Japanese companies because the system in question is the one employed by European companies to complain about Japanese exports which they perceive to be unfair. At present there are three main ways in which the WTO agreements can be used:

(1) a complaint to the Commission using the trade barriers regulation;

(2) a direct action before the EC Court of First Instance; and

(3) an action before the national courts of member states.

It should be borne in mind that private parties do not have a right to use the WTO system directly. Only sovereign states which are members of the WTO can use the dispute settlement system. Nor can private parties present their issues to a panel as intervenors or as third parties. The exclusion of private parties from the WTO has been severely criticised, not least because it detracts from the efficiency of the system if relevant evidence from the industry affected is excluded. The rule may be changed when the WTO's procedures are reviewed.

This exclusion will mean that it will be necessary for an industry to persuade its national government to bring any complaint before the WTO dispute settlement body. The great drawback of this bar to direct access by private companies to the WTO is that governments will not always be persuaded to use the dispute settlement system mechanism of the WTO, mainly because of political reasons and a fear of offending trading partners.

\section{THE TRADE BARRIERS REGULATION}

In the European system, however, there is a new regulation, Regulation 3286/94 (OJ 1994 L349/71), usually called the trade barriers regulation. Under this regulation, EU industry has a right to complain about perceived violations of WTO agreements to the Commission which will then take action on its behalf. The Commission is now beginning to take this kind of action, having received a large number of complaints following much effort on the part of European Commission officials by speaking at conferences and meetings of industrial associations, to invite people to use this new regulation.

The Commission has received a large number of complaints which it is currently processing. These include complaints by Italian silk producers against US rules of origin in the textile sector; complaints against Argentina in the leather industry; 
complaints against US anti-dumping law; and complaints from European cognac producers against Brazil. Some (if not most) of these complaints will be resolved amicably through consultation but others will end up before the WTO.

One of the interesting features of the trade barriers regulation is that its definition of Community industry does not exclude companies which have their headquarters in Japan, but which have substantial production facilities inside the EU, from complaining to the Commission under the trade barriers regulation. If a Japanese car manufacturer has substantial car assembly plants within the European Union, but experiences difficulties exporting to a non-EU country (such as Poland), it will be able to use the trade barriers regulation in exactly the same way as a German or Swedish car manufacturing company. The only limitation is that a private company cannot use the trade barriers regulation if the barrier complained against is regulated by a bilateral EU agreement. So, for example, where a Japanese car company exports to Poland, the Commission may not be able to act to help the Japanese company if the barrier complained about is a matter covered by the Polish-EU Association Agreement. In such a case, the Japanese company will need the support of an EU member state.

It is obvious that any recourse to the European Commission by Community producers will face the basic problem that the ultimate decision whether or not to proceed to the WTO will rest with the Commission rather than the complainant industry. If the Commission decides that it does not wish to take up a complaint, there are no real prospects of being able to challenge that refusal in the European courts, since the Commission enjoys a very wide discretion as to which cases it decides to act on in the exercise of its general commercial policy.

\section{DIRECT ACTION BY PRIVATE PARTIES}

The French have a proverb that 'one is always best served by oneself'. Applying this proverb to EC law, there are two basic options for a private company, wishing to ensure the observance of WTO agreements, which does not succeed in using the trade barriers regulation. The first is to attack a Community measure directly in the European courts and the second is to attack the observance by EU member states of their WTO obligations through the national courts. Both ways have some difficulties but the prospects for a successful action have dramatically improved recently.

To take a hypothetical example, if a Japanese company which exports into the EU finds itself blocked by a Community measure (such as a Community tax or a regulation ordering the way in which a particular market operates), how can it use the EC courts to obtain appropriate remedies?

Under art. 173 of the EC Treaty, a private company has the right to challenge such an EC regulation or decision by the tax authorities, provided that it can prove that the Community measure is of 'direct and individual concern' to it. The Japanese exporter would be able to present an application for the annulment of the Community regulation or decision before the EC Court of First Instance. It would argue that the EC regulation was contrary to the WTO agreements and that it should therefore be annulled.

\section{DIFFICULTIES}

There are, however, a number of difficulties with this type of 'each member state of the WTO is obliged to ensure the conformity of its laws, regulations and administrative procedures with its obligations under the [WTO] Agreement'.

This creates an unambiguous requirement of full compliance with WTO obligations by the domestic laws of member states. Equally the Community's regulations and directives must also comply with WTO requirements. In addition to the WTO Framework Agreement, many of the WTO agreements have specific requirements that the laws of WTO member states establish appropriate legal mechanisms for litigation of WTO compliance in their internal legal systems. For example, art. 13 of the Agreement on Anti-dumping provides that:

'each member whose national legislation contains provisions on antidumping measures shall maintain judicial, arbitral or administrative tribunals or procedures for the purpose, inter alia, of the prompt review of administrative actions ... such tribunals or procedures shall be independent of the authorities responsible for the determination or review in question'.

Similarly, the WTO Agreement on Government Procurement contains elaborate provisions for its domestic enforcement by private companies in cases of violations of the procurement rules of the WTO by states.

However the main question is whether private parties will be able directly to enforce compliance on WTO agreements. It is well established EC law that in appropriate cases, individuals can enforce the EC Treaty against member states where they have breached their_treaty obligations. For example, art. 12 of the EC Treaty provides that there shall be no new internal customs duties between member states. In a leading case dating from the start of the EC's history, the European Court of Justice (ECJ) ruled that individual companies could immediately enforce the EC Treaty against member states, even if there was a contrary provision of national law.

\section{DIRECT EFFECT}

In $\mathrm{EC}$ terminology, this is called giving 'direct effect' to EC law. Many articles of the EC Treaty have now been held by the ECJ to be 'directly effective'. The basic rule is that a provision of law must be clear, obviously intended to affect a defined class of individuals, and must not rely on further implementation by the member states (such as the adoption of new laws to put the EC Treaty article into practice). In the case of art. 12 of the EC Treaty, it is obvious that the requirement is merely negative, in so far as it does not require any further implementation on the part of member states; it simply prohibits new taxes on import from other member states. It was obviously clear and also obviously intended to benefit exporters and other traders of member states. It was therefore 'legally perfect'.

It is now a common occurrence for the European courts to rule that such and such an article of the EC Treaty, even though addressed to member states' governments, can create rights which individuals can enforce. Examples of 'directly effective' EC law are the treaty's rules against discrimination (art. 119ff.), promoting the free movement of EU citizens (art. 48ff.) and the competition rules of the EC Treaty (e.g. art. 85 and 86).

\section{NO DIRECT EFFECT FOR GATT}

There have been many attempts to obtain a ruling from the ECJ that the GATT and other international agreements to which the EU member states are parties are also directly effective. 
Broadly speaking, however, the ECJ has made a distinction between the association agreements and other trade agreements linking the EU and specific states, on the one hand, and the international agreements such as the GATT on the other.

In the leading case on EU association agreements, the ECJ was asked to consider whether the Portugal-EC Association Agreement could be directly effective (this case being brought in the days before Portugal became an EU member state). It ruled that the trade parts of the Portugal-EC Association Agreement were clearly intended to benefit individuals, did not require any further implementation and could in appropriate circumstances be directly enforced by individuals against member states.

Since this case, the ECJ has ruled that a wide variety of EU agreements with the outside would be directly effective, at least in certain aspects, from aid association agreements, association agreements with prospective EU member states to bilateral trade agreements.

However, as regards the GATT, the ECJ has taken a completely different view. Back in the early 1970s, the International Fruit Company tried to obtain a ruling for the ECJ that the GATT could have directly effective provisions. The Court of Justice rejected these arguments, holding the view that the GATT 1947 was not capable of being directly effective, for several reasons:

(1) The GATT 1947 was too vague in its terminology to be able to create sufficiently precise obligations to make them directly effective.

(2) There was no reciprocity between the GATT members, so that there was no guarantee that other member states of the GATT system would be equally vigilant in enforcing their obligations under the GATT Agreement.

(3) The ECJ laid great stress on the fact that the GATT was a largely consensual and diplomatic agreement: member states could veto the adoption of a GATT panel report if they disagreed with it.

This denial direct effect for the 1947 GATT has been repeated in many subsequent cases before the ECJ. It has been strongly criticised by many commentators, but its political realism is evident.

\section{EFFECT OF MEMBERSHIP}

It may be too early to venture firm opinions on the effect within the Community legal order of the EU's membership of the WTO. However it is submitted that many of the reasons the ECJ gave for denying direct effect to the 1947 GATT are no longer valid, following the creation of the WTO and the much improved dispute settlement mechanism of the Marrakech Agreements. The WTO dispute settlement mechanism is completely different from the old GATT system. Its chief new feature is that it provides for a binding system of arbitration of trade disputes with which member states are obliged to comply. Would the International Fruit Company receive a different answer from the ECJ today? My personal feeling is that it would - though, so far, there has been no case on this point.

\section{RECENT CASES}

However there are a number of recent cases which would seem to indicate that, in an appropriate case, the ECJ would be persuaded to grant individuals the right to enforce the WTO agreements directly, in other words the WTO agreements might be directly effective in appropriate cases. In the most recent case before the ECJ, the Advocate General of the court said that his remarks related:

'exclusively to the GATT in question [i.e. the 1947 GATT]. What effects the agreements ... setting up the World Trade Organisation could have ... need not be discussed here' (Amministrazione delle Finanze delo Stato v Chiquita Italia SpA (Case C-469/93) [1995] ECR I-4533).

This is a very strong hint that if the WTO agreements, as opposed to the old GATT agreements, came before the Court of Justice, they might receive a different answer. In a more recent case, concerning the International Dairy Agreement (one of the WTO agreements), the ECJ ruled that:

'when the wording of secondary community legislation [i.e. regulations or directives] is open to more than one interpretation, preference should be given as far as possible to the interpretation which renders the provision consistent with the Treaty. Similarly, the primacy of international agreements concluded by the Community over provisions of secondary community legislation means that such provisions must, so far as is possible, be interpreted in a manner that is consistent with those agreements.' (EC Commission v Federal Republic of Germany [1996] ECR I-3989).

The court concluded in this particular case that the WTO International Dairy Agreement applied to import of goods into the Community under inward processing relief arrangements.

More generally, it must be observed that many of the reasons which the ECJ gave back in 1972 in for denying the direct effect of the old GATT agreement are no longer so convincing. First, there is reciprocity between the WTO member states. All member states have to comply with the WTO and ensure the observance of the WTO agreements in their national legal systems. As art. 16.4 of the Framework Agreement says:

'each member shall ensure the conformity of its laws, regulations and administrative procedures with its obligation under the [WTO] agreements'.

Secondly, far from being a diplomatic or consensual system, the WTO agreements specifically require member states to provide means to litigate complaints of lack of compliance. (See the examples of the WTO Anti-dumping Agreement and the General Procurement Agreement quoted above.) Most important of all, the new WTO disputes settlement system is legally binding and cannot be frustrated by a veto of the member states. This was a chief concern of the ECJ in denying direct effect to the old GATT agreement. In all the circumstances, it seems that the new WTO agreements, in appropriate cases, should be able to be directly effective.

\section{DENIAL OF DIRECT EFFECT}

Much attention has been focused on the European Council's decision of December 1994 adopting the WTO agreements as part of the laws of the EU. In Decision 194/800 (OJ 1994 L336/1) the European Council made the following declaration:

by its nature, the agreement establishing the World Trade Organisation, including the annexes thereto [i.e. all the WTO agreements such as the TRIPS or the new GATT agreement] is not susceptible to being directly invoked in Community or member states' courts'.

This is a clear expression of the Council's desire that no private litigant should be able to use the WTO agreements in the courts of the member states or before the ECJ. As the Commission explained in its report of the Council (see 
$\operatorname{COM}(94) 1433$ Final), at the time when the decision was taken:

'it is important for the WTO agreements and its annexes not to have direct effect, that is whereby private individuals who are natural or legal persons could invoke it under national law. It is already known that the United States and many other of our trading partners will explicitly rule out any such direct effect. Without an expressed stipulation of such exclusion in the community instrument of adoption, a major imbalance would arise in the actual management of the obligations of the community and other countries.

The precise legal effect of the Council's declaration is controversial but several observations can immediately be made. First there is no statement in the WTO agreement or its various individual agreements stating or purporting to state their legal effects within the legal systems of the WTO member states. The only exception is the introductory note added by the Community and the EU member states in their schedule of commitments under the GATT; this states that:

'The rights and obligations arising from the GATT, including the schedule of commitments, shall have no self-executing effect and thus confer no rights directly to individual natural persons or judicial persons.'

Otherwise there are no reservations by the EU states in the WTO agreements as to their legal effect within the domestic legal system of the member states - a question which must, on basic principles of public international law relating to treaties, remain a matter for the domestic legal systems of individual member states.

Secondly, while there is no legal prohibition on Community institutions choosing to declare their views on the legal effects of external trade agreements, it is conventional for them to do so at the conclusion of such agreements: No such declaration was made by the EU on the conclusion of the Uruguay Round Agreements, and the Community has been criticised for this lack of foresight.

\section{DECLARATION PERSUASIVE ONLY}

The Council's declaration remains thus both unilateral and ex post facto. Such a unilateral act by the Council cannot, of course, alter the legal character of its act, something which only the ECJ is competent to decide. The ECJ will respect the express stipulations of an international agreement in determining the nature of its effects. But in the absence of such express determination in the treaty, as in the present case, the ECJ will determine the legal consequence of a treaty on a caseby-case basis. The unanimous view, denying direct effect to the WTO agreements, by the Commission (as negotiator), by the Council and the Parliament jointly responsible for their legislative adoption, is therefore only persuasive - although such persuasiveness may be decisive in the minds of national courts.

It is submitted, therefore, that the Council's declaration in Recital 11 of the WTO decision is only persuasive, and that the ECJ, if called upon to decide the issue, will observe the Council's views with all respect due to it but that, in the final analysis, it will make up its own mind on the direct effectiveness of each WTO agreement provision submitted to its scrutiny. The exclusion of the courts which the Council attempts to create as regards the WTO agreements in its decision does not have any legal force: it is no more than an expression of its potential wishes.

\section{ALTERNATIVE METHODS}

The alternative method to direct enforcement of the WTO agreements before the ECJ is through the national courts of the member states. For example, if a Japanese company had to pay anti-dumping duties which it considered were imposed in violation of the agreement on anti-dumping, it could refuse to pay the duties levied by the customs authorities of the member states and challenge the national measures in the national courts. Under English law, this would be an application to the High Court for judicial review of the administrative acts of $\mathrm{HM}$ Customs \& Excise.

The Japanese company would argue that the WTO agreements had superior force of law and over-ruled any contrary EC legal measure or UK measure made pursuant to the EC law. The EC Treaty provides a procedure, known as a 'reference', whereby such questions of interpretation of the validity of national laws compared to the EC Treaty and the law that arise from it can be examined by the ECJ. The national courts determine which questions of law need to be interpreted by the ECJ and then refer them to it while stopping the proceedings in the national courts. Effectively this is an effort to ensure compliance with WTO's obligations through indirect means by way of a sort of compliance review by the ECJ. In the case involving the International Dairy Agreement, the ECJ said that EC law had so far as possible to be interpreted in conformity with international agreements such as the WTO. This type of compliance review is being increasingly used in anti-dumping cases.

\section{THREE CASES}

So far, there have been three attempts in national courts to use the WTO's agreements in this way. Two were brought in the High Court in London and one in Ireland. In these three cases, which all concern the Intellectual Property Agreement of the WTO (the TRIPS), the national courts were asked to decide whether or not to allow direct effect to the WTO agreements. It has to be said that the result has been disappointing in the English High Court, where the judges were not sufficiently aware of international developments to give proper judgments.

In the first case, $R v$ the Comptroller of Patents, Designs and Trademarks ex parte Lenzig (not yet reported, 20 December 1996) the judge dismissed the arguments that the WTO agreements could be directly effective for several reasons. First, he was not convinced that the new WTO dispute settlement system was any different from the old GATT system. For him it was a 'distinction without a difference', (thereby ignoring the legally binding nature of WTO's dispute resolution and the five cases that have gone through the new WTO's procedure). He also laid great stress on the Council's declaration denying direct effect to the WTO agreements, describing as 'fantastic' the idea that the ECJ might decide in a way contrary to the express wishes of the 15 member states, the Council and the Commission. Of course, this was precisely what the European Court has done on many occasions, manifesting its traditional independence from the politicians in the Council.

Unfortunately, in the second English case, Azrack-Hamway International Inc's Licence of Right (Design Right and Copyright) Application (1997) RPC 134, the judge's attention was not drawn to the new dispute settlement mechanism sufficiently clearly so that he could understand why the new WTO dispute settlement body had fundamentally changed the legal situation. In both English cases, applications to enforce the WTO agreements directly were therefore rejected. 
However, a different conclusion was reached in the High Court in Ireland in Allan \& Hanbury Ltd $v$ Comptroller of Patents Designs and Trademarks (1997) Fleet Street Reports, where the grant of a compulsory licence of a patent was overturned because it conflicted with the TRIPS Agreement.

There is therefore a conflicting situation where different member states at the first level of the court hierarchy have taken diametrically opposed views. It will need appeals to the higher courts such as the House of Lords for the matter to be resolved.

\section{CONCLUSION}

What conclusions can one derive from all this? First, there is absolutely no doubt that the new WTO dispute settlement system is a success, as is witnessed by the flood of cases that have been presented by member states since the introduction of the system in February 1996. Indeed, the WTO is a victim of its own success, in so far as it is not able to cope with its huge new workload.

The European Commission is actively trying to promote the interest of Community industry by bringing complaints to the WTO. No doubt a similar attitude is expressed by the Japanese authorities. However, as discussed above, a Japanese company with substantial production facility within the EU will be treated as a Community producer and should be able to use the new trade barriers regulation as much as normal Community producers.

Secondly, that the recent cases before the ECJ indicate that, in an appropriate case, the court may well depart from its past practice in the 1947 GATT and allow individuals and private companies to enforce the WTO agreements directly against member states which have breached their obligations. This would be a tremendous weapon to use in opening up markets and in ensuring that industry obtains full benefits from the new WTO agreements.

Thirdly, despite the conflicting results of the cases that have so far occurred before the national courts of the member states, there appears to be a growing willingness by those courts to accept arguments based on international law and the WTO agreements. There will sooner or later be a reference to ECJ from a national court of a member state which will further clarify the extent to which individuals can raise the WTO agreements in a national court.

By way of conclusion, I would suggest that when Japanese exporters are faced with trade barriers within the Community legal system or practices by the European Commission in, for example, the application of anti-dumping rules, it should look at the possibility of using the WTO agreements as a further weapon. After all, the WTO agreements - and the courts which are there to give effect to them - were supposed to create a new climate for international trade and both Europeans and Japanese are supposed to benefit from this.

\section{Philip Ruttley}

Garretts

This text was originally delivered at a seminar with the Japanese Machinery Exporters' Association, held in Tokyo on 11 July 1997

\title{
Making its Mark?
}

\author{
by Paul Harris \& Paul Garland
}

Recent years have seen a developing picture in the law relating to trade marks. Paul Harris and Paul Garland review decisions made under the Trade Marks Act 1994 and look at a number of passing off cases.

$\mathrm{W}$ e have now had just over two years of the new substantive and procedural approaches to trade marks and whilst there have been a few surprises, from the litigation point of view, it would generally be fair to say that there has been a lot 'more of the same'.

Passing off actions, too, have slowly been evolving and the last two years' important cases are digested below.

\section{TRADE MARK REGISTRY PRACTICE}

The case of Konings Graanstrokrij (NV)'s Application - St Trudo Trade Mark [1995] FSR 345, though not heard in the registry, related to Trade Mark Registry practice. Konings Graanstrokrij NV applied to expunge two marks for St Trudo in Classes 32 and 33 registered in the name of McCormick (UK) plc. The application was dealt with on the basis of the transitional provisions of the Trade Marks Act 1994. The application succeeded and the concurrent jurisdiction of the registrar and the court was preserved and noted.

However, the main point of this case, which gave rise to great concern amongst trade mark agents at the time was that $\mathrm{Mr}$ Justice Ferris held that second-hand or more remote hearsay evidence was inadmissible in rectification proceedings; the strict 